\title{
ANALISIS KESESUAIAN EKOWISATA MANGROVE DESA KAHYAPU PULAU ENGGANO
}

\author{
Oleh \\ Dessi Fitriana, Yar Johan, dan Person Pesona Renta \\ Program Studi IImu Kelautan Fakultas Pertanian Universitas Bengkulu, Bengkulu \\ dessi fitriana14@yahoo.com \\ Received July 2016, Accepted August 2016
}

\begin{abstract}
ABSTRAK
The purpose of this study was to identify the potential of mangrove ecosystems as mangrove ecotourism objects and calculate suitability mangrove ecotourism in the village Kahyapu Enggano. This research was conducted using survey methods, measurements in the field and ecological suitability determination based on the multiplication of weights and scores obtained from any of the parameters consisting of five parameters: the thickness of the mangrove, mangrove density, types of mangrove , tidal and biota object. Mangrove ecosystem in the Village Kahyapu Enggano has the potential to be developed as an ecotourism mangrove. Based on the results, the results of IKW ( Travel Suitability Index) at the stations I $60 \%$ category S2 (Match ), Station II $66 \%$ category S2 (Match ) and Station III $71 \%$ category S2 (Match ).
\end{abstract}

Keywords : ecotourism mangrove, suitability region, village kahyapu, enggano island.

\section{PENDAHULUAN \\ Latar Belakang}

Pulau Enggano adalah salah satu pulau terdepan di Indonesia yang berada di Samudra Hindia. Secara geografis, Pulau Enggano terletak pada posisi $05^{\circ} 31^{\prime} 13^{\prime \prime}$ LS dan 102'16'00" BT. Berdasarkan administratif, Pulau Enggano memiliki satu Kecamatan yang termasuk dalam wilayah Kabupaten Bengkulu Utara, Provinsi Bengkulu. Keseluruhan luas wilayah daratan Pulau Enggano terdiri dari enam Desa yaitu Kahyapu, Kaana, Malakoni, Apoho, Meok, dan Banjarsari. Jarak Pulau Enggano ke lbu Kota Provinsi Bengkulu mencapai 90 mill laut atau $\pm 166,68 \mathrm{~km}$, sedangkan jarak terdekat ke kota Kaur, Kabupaten Bengkulu Selatan yaitu 60 mil laut atau \pm 111,12 km (Ta'alidin dkk., 2003).

Pulau Enggano memiliki banyak potensi sumberdaya alam yang dapat dikelola, khususnya dalam bidang ekosistem mangrove. Pengembangan potensi ekosistem mangrove ini akan berperan secara langsung terhadap keadaan ekosistem pesisir, dimana ekosistem mangrove memiliki fungsi penting baik secara fisik, biologi maupun ekonomi untuk masyarakat. Fungsi ekosistem mangrove sebagai peredam gelombang dan angin badai, pelindung dari abrasi, penahan lumpur, perangkap sedimen, daerah asuhan (nursery groud), daerah mencari makanan (feeding ground), dan daerah pemijahan (spawning ground) berbagai jenis ikan, udang, dan biota laut lainnya, Penghasil kayu untuk bahan konstruksi, kayu bakar, bahan baku arang, dan bahan baku kertas (pulp), serta tempat ekowisata (Saru, 2014).

Ekosistem mangrove banyak memberikan fungsi ekologis dan menjadi salah satu produsen utama dalam perikanan laut. Ekosistem mangrove juga dapat membantu pengembangan dalam bidang sosial dan ekonomi masyarakat sekitar pesisir pantai. Keadaan ekosistem mangrove di Desa Kahyapu Pulau Enggano yang masih tergolong alami, hal ini dikarenakan Pulau Enggano salah satu pulau yang masih jarang dikunjungi oleh banyak orang. Komposisi jenis ekosistem mangrove yang ditemukan sebanyak 8 (delapan) jenis mangrove sejati yaitu jenis acrostichum, 
rhizopora apiculata, sonneratia alba, dan xylocarpus granatum (Agustini, 2014). Keadaan wilayah pesisirnya masih terjaga dengan baik, sehingga pulau ini sangat potensial untuk dikembangkan khususnya pada kawasan ekosistem mangrove, melihat potensi sumberdaya alam seperti ekosistem mangrove yang masih alami maka sangat menarik untuk dijadikan sebagai ekowisata mangrove.

Menurut Yulianda (2007), Ekowisata merupakan suatu bentuk pemanfaatan sumberdaya alam yang mengandalkan jasa alam untuk kepuasan manusia. Ekowisata pesisir dan laut tidak hanya menjual tujuan atau objek, tetapi juga menjual filosofi dan rasa sehingga tidak akan mengenal kejenuhan bagi wisatawan yang menggemari dibidang pariwisata (Tuwo, 2011 dalam Fahriansya, 2012). Ekowisata (Ecotourism, green tourism atau alternative tourism), merupakan ekowisata berorientasi pada lingkungan untuk menjembati kepentingan perlindungan sumberdaya alam/lingkungan dan industri kepariwisataan (Burnn, 1995 dan META, 2002 dalam Yulianda dkk., 2010).

Mengingat pentingnya ekosistem mangrove bagi keberlangsungan mahluk hidup, sudah sewajarnya diperlukan upayah pengelolaan yang mempertimbangkan keberlanjutan atau kelestarian ekosistem mangrove dengan menjadikan daerah ekosistem mangrove yang masih alami tersebut menjadi kawasan ekowisata mangrove, selain menjaga keberlanjutan dan kelestarian dari ekosistem mangrove, wisatawan juga dapat menikmati keindahan ekowisata mangrove yang ada di Desa Kahyapu Pulau Enggano.

Berdasarkan dari uraian diatas, sampai saat ini belum ada data dan penelitian terkait ekowisata mangrove. Sehingga, penulis tertarik untuk melakukan penelitian tentang analisis kesesuaian ekowisata mangrove di Desa Kahyapu Pulau Enggano.

\section{Tujuan dan Manfaat Penelitian}

Penelitian ini bertujuan (1) Mengidentifikasi potensi ekosistem mangrove di Desa Kahyapu Pulau Enggano sebagai objek ekowisata mangrove, (2) Menghitung kesesuaian kawasan ekowisata mangrove di Desa Kahyapu Pulau Enggano. Penelitian ini diharapkan dapat memberikan pengetahuan bagi masyarakat Desa Kahyapu dan sekitar Pulau Enggano tentang ekowisata mangrove, dan tersedia data mengenai potensi dan data aktual ekosistem mangrove, serta sumber referensi dalam pembangunan ekowisata di Desa Kahyapu Pulau Enggano, selain itu sebagai bahan masukan bagi pihak Pemerintah Daerah dalam pembangunan sektor pariwisata sehingga Desa Kahyapu Pulau Enggano dapat menjadi salah satu ekowisata mangrove yang dikenal oleh kalangan banyak orang.

\section{METODE PENELITIAN Tempat dan Waktu Penelitian}

Penelitian ini telah dilaksanakan pada bulan April - Mei 2016, tempat penelitian berlokasi di Desa Kahyapu Pulau Enggano Kabupaten Bengkulu Utara (Lihat Gambar 1).

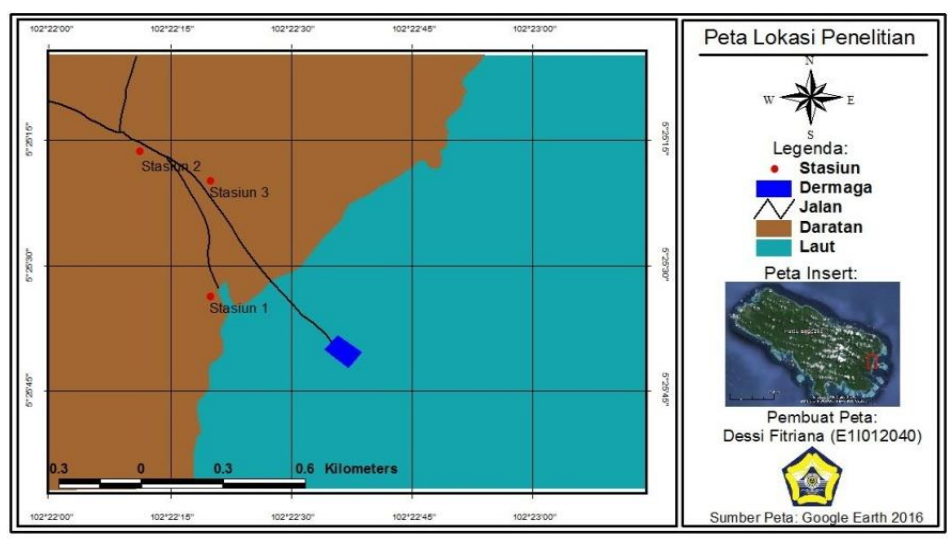


Gambar 1. Peta Lokasi Penelitian.

\section{Alat dan Bahan}

Alat dan bahan yang dipergunakan dalam penelitian (Lihat Tabel 1).

Tabel 1. Alat dan bahan penelitian.

\begin{tabular}{cll}
\hline No & \multicolumn{1}{c}{ Alat dan Bahan } & \multicolumn{1}{c}{ Kegunaan } \\
\hline 1 & GPS & Menentukan titik koordinat sampling \\
2 & Meteran & Pengukuran luas areal mangrove \\
3 & Alat Tulis & Mencatat hasil pengamatan dilapangan \\
4 & Kamera & Dokumentasi gambar \\
5 & Buku Identifikasi Mangrove. & Pedoman identifikasi mangrove \\
& Noor dkk., (2006). & \\
6 & Buku Identifikasi Biota & Pedoman identifikasi biota \\
& Anam (2012). & \\
7 & Kuisoner & Sebagai daftar pertanyaan wawancara \\
8 & Serokan & Menangkap biota air \\
9 & Tali Rafia & Membuat transek \\
10 & Kantong Plastik & Tempat sampel \\
11 & Komunitas Mangrove & Objek pengamatan penelitian \\
12 & Notebook & Sebagai penyusunan laporan \\
13 & Microsoft Word & Membantu pembuatan dokumen \\
14 & Microsoft Exel & Membantu mengolah data \\
15 & Flash Disk & Menyimpan data \\
16 & Printer & Mencetak dokumen \\
17 & Literatur lainya & Data sekunder untuk mendukung penelitian \\
\hline & &
\end{tabular}

\section{Sumber Data}

Data primer yaitu data yang langsung diperoleh dari lapangan, meliputi pengukuran ketebalan mangrove, kerapatan mangrove, keanekaragaman jenis mangrove, pasang surut dan obyek biota yang berasosiasi dengan ekosistem mangrove. Dalam penelitian ini data juga diperoleh dari hasil pertanyaan responden, terhadap wawancara pengisian kuesioner yang disampaikan langsung oleh peneliti oleh pihak-pihak berkepentingan yang berkaitan dengan kegiatan penelitian di Desa Kahyapu Pulau Enggano. Data sekunder diperoleh dari berbagai sumber yang berkaitan dengan penelitian seperti jurnal, tesis, buku yang berkaitan dengan ekowisata mangrove, Dinas Kelautan Perikanan (DKP) Bengkulu Utara, Dinas Kebudayaan dan Pariwisata Provinsi Bengkulu, Dishidros TNI-AL, Kepala Camat, Kepala Desa, Tokoh Masyarakat, Nelayan, Pemuda dan Data Penelitian ekosistem mangrove yang pernah dilakukan sebelumnya data tentang kondisi umum Pulau Enggano meliputi sejarah kawasan, luas dan letak, serta potensi sumberdaya alam, dan lain-lain.

\section{Penentuan Lokasi Penelitian}

Metode penelitian yang digunakan adalah Purposive Sampling yang dibagi 3 stasiun berdasarkan kondisi ekologi Desa Kahyapu Pulau Enggano. Penelitian dilakukan pada 3 (tiga) stasiun yang berbeda dimana pada setiap stasiun terdapat 3 (tiga) garis transek dan pada 1 (satu) garis transek terdapat 3 (tiga) petak plot pengambilan sampel. Jalur transek pengamatan dimulai dengan arah tegak lurus dari arah laut ke arah darat sepanjang adanya ekosistem mangrove, dimana jalur transek yang akan dibuat harus mewakili wilayah kajian dan harus mewakili setiap zonasi ekosistem mangrove yang terdapat di wilayah kajian masing-masing transek dalam sub stasiun penelitian memiliki jarak 100 meter, sedangkan jarak antara stasiun sepanjang 300 meter. 


\section{Metode Pengumpulan Data Data Ekologi}

\section{Ekosistem Mangrove}

Secara umum pengambilan data ekosistem mangrove dilakukan dengan menggunakan transek garis (line transect). Transek garis yang dibuat dengan cara menarik jalur transek yang menggunakan tali rafia dengan arah tegak lurus dari arah laut ke arah darat sepanjang adanya ekosistem mangrove. Data ekosistem mangrove diambil dari setiap transek menggunakan metode transek kuadran dengan kategori Sofian dkk., (2012).

1. Kategori pohon. Pada petak contoh $10 \times 10 \mathrm{~m}^{2}$ dengan diameter batang $\geq 10 \mathrm{~cm}$ pada ketinggian $\geq 1,5 \mathrm{~m}$

2. Kategori anakan. Pada petak contoh $5 \times 5 \mathrm{~m}^{2}$ dengan diameter batang $<10 \mathrm{~cm}$ dan tinggi tanaman $\geq 1,5 \mathrm{~m}$

3. Kategori semai. Pada petak contoh $2 \times 2 \mathrm{~m}^{2}$ dengan ketinggian $<1,5 \mathrm{~m}$.

\section{Obyek Biota}

Data mengenai obyek biota diamati secara visual di lokasi penelitian pada setiap petak/plot misalnya: ikan, udang, kepiting, dan moluska, kemudian ditangkap dengan menggunakan alat tangkap serokan. Setelah didapatkan biota-biota yang ada disetiap petak/plot, maka didokumentasikan dengan menggunakan kamera, selanjutnya biota-biota yang ditangkap menggunakan serokan tersebut setelah selesai lalu dilepaskan kehabitatnya semula.

\section{Data Kualitas Air}

Parameter kualitas air pendukung yang diambil adalah pasang surut. Data pasang surut diperoleh dari data sekunder yang berkaitan dengan pasang surut di Pulau Enggano yang diperoleh dari Dishidros TNI AL, (2016).

\section{Data Sosial}

Data sosial diperoleh dari wawancara langsung di lapangan dengan teknik purposive sampling yaitu teknik pengambilan sampel sumber data dengan pertimbangan tertentu (Safina $d k k$., 2014). Data sosial diperoleh dari hasil pertanyaan, terhadap wawancara pengisian kuesioner yang disampaikan langsung oleh peneliti oleh pihak-pihak berkepentingan yang berkaitan dengan kegiatan penelitian di Desa Kahyapu Pulau Enggano. Responden meliputi: kepala camat pulau enggano, kepala desa, sekretaris desa, perangkat desa, nelayan, penjual kepiting, kepala suku, pemuda dan lain-lain.

\section{Analisa Data \\ Analisis Ketebalan Mangrove}

Analisis Ketebalan mangrove secara deskriftif yaitu hasil akhir yang didapatkan disajikan kedalam gambar atau grafik, sehingga mempermudah untuk dibaca.

\section{Analisis Kerapatan Jenis Mangrove}

Menurut (Bengen, 2000), Kerapatan jenis (D) merupakan jumlah tegakan jenis ke-i dalam suatu unit area. Data vegetasi ekosistem mangrove yang dikumpulkan, digunakan untuk menilai lingkungan secara ekologi, yaitu dibatasi pada penentuan nilai kerapatan mangrove saja, yang merupakan salah satu aspek dalam penentuan kesesuaian suatu kawasan ekowisata mangrove. Perhitungan analisis mangrove merujuk kepada Bengen (2000).

\section{Analisis Jenis Mangrove}


Analisis data jenis mangrove secara deskriptif dengan cara disajikan kedalam gambar atau grafik, analisis jenis mangrove mengacu pada Noor dkk. (2006).

\section{Analisis Obyek Biota}

Analisis data obyek biota secara deskriftif dengan cara disajikan kedalam bentuk gambar atau grafik yang ditampilkan, analisis obyek biota mengacu pada Anam (2012).

\section{Analisis Pasang Surut}

Data pasang surut diperoleh dari Dishidros TNI-AL, (2016). Kemudian analisis data olahan pasang surut dengan menggunakan gambar atau grafik yang disajikan, agar mempermudah untuk dibaca.

\section{Analisis Kesesuaian Kawasan Ekowisata Mangrove}

Menurut Yulianda (2007), Pembobotan dan nilai untuk mengetahui besar skor dari penggabungan beberapa parameter sehingga akan terdapat perbedaan skor antara kelas yang satu dengan kelas yang lain, selanjutnya digunakan untuk memberi klasifikasi kesesuaian kawasan ekowisata mangrove. Matrik kesesuian ekowisata mangrove merujuk pada Yulianda (2007).

Penentuan indeks kesesuaian kawasan ekowisata mangrove dapat digunakan rumus dibawah ini Yulianda (2007). Matriks kesesuaian diatas maka dapat ditentukan penilaian untuk kesesuaian kawasan ekowisata mangrove (Lihat Tabel 2).

Tabel 2. Interval Nilai Kesesuaian Berdasarkan Kategori Kesesuaian.

\begin{tabular}{clc}
\hline No. & \multicolumn{1}{c}{ Kategori } & Interval Kesesuaian \% \\
\hline 1. & S1 (Sangat Sesuai) & $75-100$ \\
2. & S2 (Sesuai) & $50-74,9$ \\
3. & S3 (Sesuai Bersyarat) & $25-49,9$ \\
4. & N (Rendah) & 24,9 \\
\hline
\end{tabular}

Sumber: Modifikasi Yulianda (2007).

\section{HASIL DAN PEMBAHASAN \\ Analisis Ketebalan Mangrove}

Berdasarkan hasil penelitian yang telah dilakukan di kawasan ekosistem mangrove di Desa Kahyapu didapatkan hasil pengukuran ketebalan ekosistem mangrove pada setiap lokasi stasiun penelitian (Lihat Gambar 2).

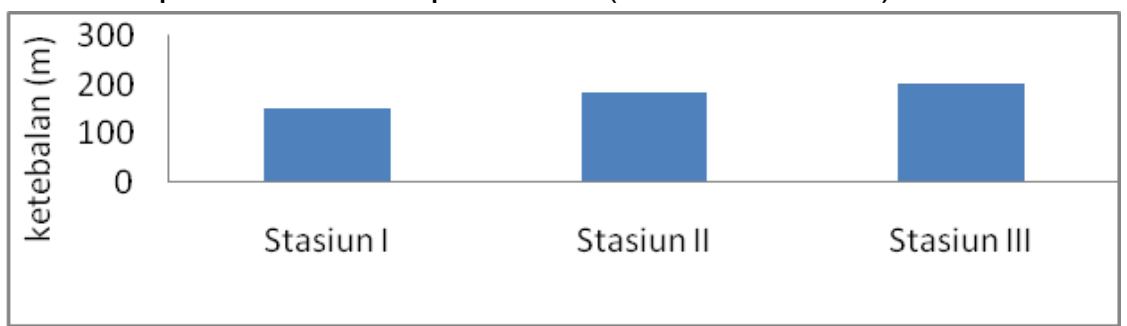

Gambar 2. Grafik Ketebalan Mangrove (m)

Pada lokasi Stasiun I didapatkan nilai ketebalan mangrove mencapai $153 \mathrm{~m}$ ini dikarenakan pada Stasiun I ini ekosistem mangrovenya tumbuh sangat dekat dengan laut dan rumah warga ekosistem mangrove yang ada pada Stasiun I ini sangat jarang namun mangrove kategori pohonya besar dan tinggi. Pada lokasi Stasiun II didapatkan nilai ketebalan mangrove mencapai $185 \mathrm{~m}$ ekosistem mangrove yang ada pada stasiun II ini terletak berdekatan dengan aliran air sungai dan berada lebih dekat ke arah daratan, sehingga pengaruh air laut/salinitas menjadi lebih sedikit. Sedangkan pada Stasiun III didapatkan nilai ketebalan mangrove mencapai 204 m ekosistem mangrove pada Stasiun III ini langsung berhadapan dengan laut sehingga kondisi ekosistem mangrove yang ada di Stasiun III ini selalu tergenang oleh air pada saat pasang normal, sehingga pengaruh air laut didalamnya menjadi lebih tinggi. Sama halnya pada 
hasil penelitian yang didapatkan oleh Wibowo (2015), mengatakan bahwa pada lokasi penelitian Stasiun I dan Stasiun II mencapai 127 m dan 168 m sedangkan pada Stasiun III $183 \mathrm{~m}$.

Analisis Kerapatan Jenis Mangrove Kategori Pohon

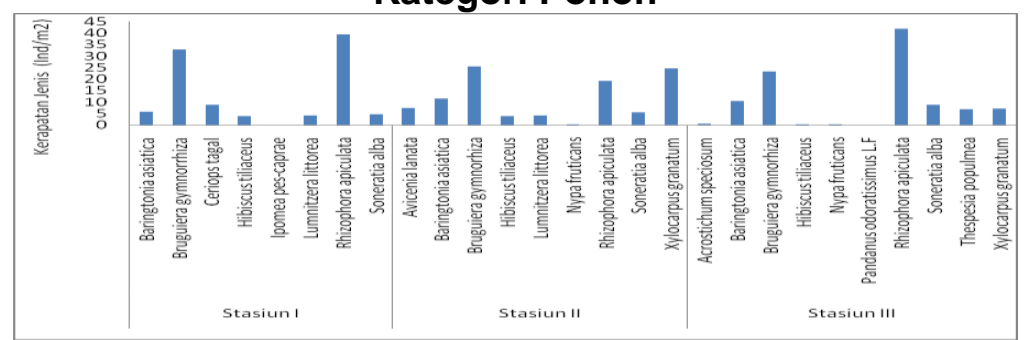

Gambar 3. Kerapatan Jenis Kategori Pohon

Nilai kerapatan jenis kategori pohon pada Stasiun I, jenis mangrove Bruguiera gymnorrhiza dan Rhizophora apiculata terlihat lebih banyak ditemui pada Stasiun I sehingga pada jenis mangrove ini nilai kerapatannya lebih tinggi diantara jenis mangrove yang lainya, bila dirata-ratakan nilai kerapatan jenis ekosistem mangrove pada stasiun I yaitu $12,50 \mathrm{ind} / \mathrm{m}^{2}$. Pada Stasiun II nilai kerapatan jenis mangrove Bruguiera gymnorhiza, Xylocarpus granatum dan Rhizophora apiculata lebih banyak ditemui pada stasiun II sehingga pada jenis mangrove ini nilai kerapatanya lebih tinggi diantara jenis mangrove yang lainya, ,bila dirata-ratakan nilai kerapatan jenis ekosistem mangrove pada Stasiun II yaitu $11,41 \mathrm{Ind} / \mathrm{m}^{2}$. Sedangkan pada Stasiun III nilai kerapatan jenis kategori pohon, jenis Rhizophora apiculata dan Bruguiera gymnorhiza lebih banyak ditemui pada stasiun III, sehingga pada jenis mangrove ini nilai kerapatanya lebih tinggi diantara jenis mangrove yang lainya, bila dirata-ratakan nilai kerapatan jenis ekosistem mangrove pada Stasiun II yaitu 10,00 Ind/ $\mathrm{m}^{2}$.

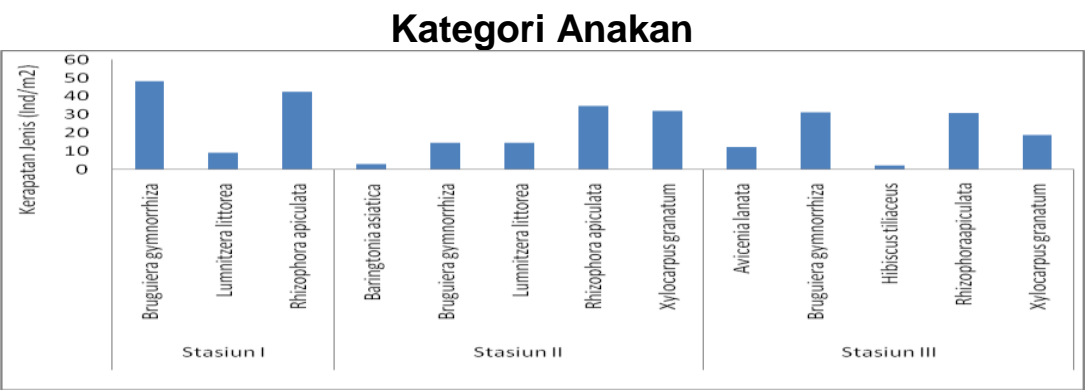

Gambar 4. Kerapatan Jenis Kategori Anakan

Stasiun I jenis mangrove Bruguiera gymnorrhiza dan Rhizophora apiculata terlihat lebih banyak ditemukan. pada Stasiun I sehingga pada jenis mangrove ini nilai kerapatannya lebih tinggi diantara jenis mangrove yang lainya, bila dirata-ratakan nilai kerapatan jenis ekosistem mangrove pada Stasiun I yaitu $33.3 \mathrm{ind} / \mathrm{m}^{2}$. Pada Stasiun II nilai kerapatan jenis kategori anakan pada Stasiun II jenis mangrove Rhizophora apiculata dan Bruguiera gymnorhiza yang paling banyak ditemukan sehingga nilai kerapatanya lebih tinggi diantara jenis mangrove yang lainya, bila dirata-ratakan nilai kerapatan jenis ekosistem mangrove pada Stasiun II yaitu $20 \mathrm{Ind} / \mathrm{m}^{2}$. Sedangkan pada Stasiun III nilai kerapatan jenis kategori anakan pada stasiun III jenis ekosistem mangrove yang ditemukan Rhizophora apiculata, Bruguiera gymnorhiza, Xylocarpus granatum, Avicenia lanata, dan Hibiscus tiliaceus. Namun jenis ekosistem mangrove yang paling banyak ditemukan pada Stasiun III ini yaitu jenis ekosistem mangrove Rhizophora apiculata dan Bruguiera gymnorhiza yang paling sering muncul. Bila dirataratakan hasil perhitungan nilai kerapatan jenis ekosistem mangrove pada Stasiun III ini yaitu $19.14 \mathrm{lnd} / \mathrm{m}^{2}$. 


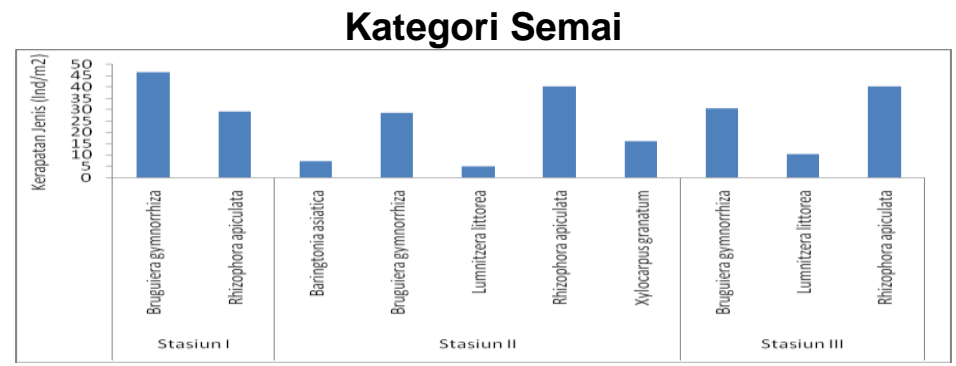

Gambar 5. Kerapatan Jenis Kategori Semai

Stasiun I jenis ekosistem mangrove yang ditemukan jenis ekosistem mangrove Bruguiera gymnorhiza dan Rhizophora apiculata untuk jenis Bruguiera gymnorhiza didapatkan nilai kerapatanya 46,66 Ind/ $\mathrm{m}^{2}$ sedangkan Rhizophora apiculata didapatakan nilai kerapatanya $29,02 \mathrm{Ind} / \mathrm{m}^{2}$, bila dirata-ratakan nilai kerapatan jenis kategori semai pada Stasiun I yaitu $37,84 \mathrm{Ind} / \mathrm{m}^{2}$. Pada Stasiun II nilai kerapatan jenis ekosistem mangrove Rhizophora apiculata 40,35 Ind/ $\mathrm{m}^{2}$, Bruguiera gymnorhiza 28,56 $\mathrm{Ind} / \mathrm{m}^{2}$, Xylocarpus granatum $15,90 \mathrm{Ind} / \mathrm{m}^{2}$, Baringtonia asiatica $7,14 \mathrm{Ind} / \mathrm{m}^{2}$ dan Lumnitzera littorea $4,8 \mathrm{Ind} / \mathrm{m}^{2}$, bila dirata-ratakan nilai kerapatan jenis kategori semai pada Stasiun II yaitu $19,36 \mathrm{Ind} / \mathrm{m}^{2}$.

Sedangkan pada Stasiun III, nilai kerapatan jenis ekosistem mangrove Rhizophora apiculata 40,15 Ind/ $/ \mathrm{m}^{2}$, Bruguiera gymnorhiza $30,69 \mathrm{Ind} / \mathrm{m}^{2}$, dan Lumnitzera littorea $10,23 \mathrm{Ind} / \mathrm{m}^{2}$. Rata-rata nilai kerapatan jenis kategori semai pada Stasiun III yaitu 27,02 $\operatorname{lnd} / \mathrm{m}^{2}$.

\section{Analisis Jenis Mangrove}

Berdasarkan dari hasil penelitian dilapangan jenis mangrove yang ditemukan di Desa Kahyapu (Lihat Tabel 3).

Tabel 3. Komposisi Jenis Mangrove di Desa Kahyapu Pulau Enggano.

\begin{tabular}{|c|c|c|c|c|}
\hline \multirow{2}{*}{ No } & \multirow{2}{*}{ Jenis Mangrove } & \multicolumn{3}{|c|}{ Lokasi Penelitian } \\
\hline & & Stasiun I & Stasiun II & Stasiun III \\
\hline 1 & Acrostichum speciosum & - & - & + \\
\hline 2 & Avicennia lanata & - & + & - \\
\hline 3 & Bruguiera gymnorrhiza & + & + & + \\
\hline 4 & Ceriops tagal & + & - & - \\
\hline 5 & Lumnitzera littorea & + & + & - \\
\hline 6 & Rhizopora apiculata & + & + & + \\
\hline 7 & Sonneratia alba & + & + & + \\
\hline 8 & Xylocarpus granatum & - & + & + \\
\hline 9 & Barringtonia asiatica * & + & + & + \\
\hline 10 & Hibiscus tiliaceus $L$ * & + & + & + \\
\hline 11 & Ipomea pes-caprae * & + & - & - \\
\hline 12 & Nypa fruticans * & - & + & + \\
\hline 13 & Pandanus odoratissimus L.f. * & - & - & + \\
\hline 14 & Thespesia populnea * & - & - & + \\
\hline
\end{tabular}

Stasiun I jenis mangrove yang ditemukan sebanyak 8 jenis yang terdiri dari mangrove sejati Bruguiera gymnorrhiza, Ceriops tagal, Lumnitzera littore, Rhizopora apiculata, Sonneratia alba, dan mangrove ikutan Barringtonia asiatica, Hibiscus tiliaceus L, dan Ipomea pes-caprae. Stasiun II yaitu jenis mangrove sejati yang ditemukan diantaranya Avicennia lanata, Bruguiera gymnorrhiza, Lumnitzera littorea, Rhizopora apiculata, Sonneratia alba, dan Xylocarpus granatum. Sedangkan untuk jenis non mangrove/mangrove ikutan diantaranya Barringtonia asiatica, Hibiscus tiliaceus L, dan Nypa fruticans. Pada Stasiun III jenis mangrove sejati diantaranya: Acrostichum speciosum, Bruguiera gymnorrhiza, Rhizopora apiculata, Sonneratia alba, dan Xylocarpus granatum. Kemudian untuk jenis non mangrove atau mangrove ikutan 
yang ditemukan diantaranya Barringtonia asiatica, Hibiscus tiliaceus L, Nypa fruticans, Pandanus odoratissimus L.f., Passiflora foetida, dan Thespesia populnea.

\section{Analisis Pasang Surut}

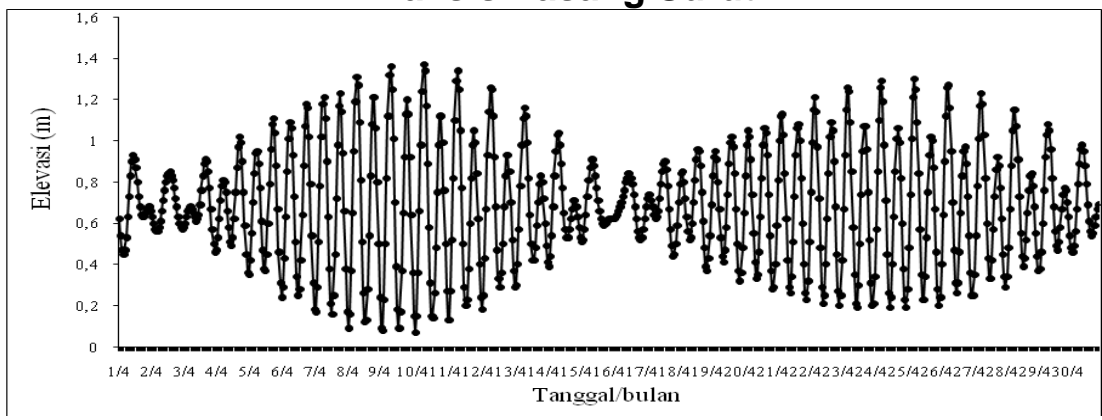

Gambar 6. Grafik Pasang Surut Pulau Enggano (Dishidros TNI AL, 2016).

Data pasang surut yang diperoleh dari Dishidros TNI-AL (2016), terhitung mulai tanggal 1 april - 30 april, kondisi muka air tertinggi 1.37 meter, nilai rata-rata muka air tinggi tertinggi 1.20 meter, nilai rata-rata muka air tinggi 1.03 meter, nilai ratarata muka air rendah 0.38 meter, nilai rata-rata muka air rendah terendah 0.07 meter, nilai terendah muka air 0.22 meter, tunggang pasang surut 1.30 meter dan tinggi ratarata harian muka air laut di lokasi penelitian 0.68 meter. Jenis Pasang Surut yang ada di Desa Kahyapu Pulau Enggano yaitu merupakan jenis pasang surut harian ganda (Semi Diurnal Tide) pasang surut yang terjadi dua kali pasang dan dua kali surut yang tingginya hampir sama dalam satu hari. Pasang surut juga digunakan sebagai parameter pembangunan ekowisata mangrove, karena dengan data pasang surut akan mempermudah dalam proses pembangunan bangunan atau sarana yang berada pada zona yang mengalami pasang surut.

\section{Analisis Obyek Biota}

Berdasarkan dari hasil penelitian dilapangan obyek biota yang ditemukan di Desa Kahyapu pada setiap stasiun yaitu (Lihat Tabel 4).

Tabel 4. Obyek Biota yang terdapat di Desa Kahyapu Pulau Enggano

\begin{tabular}{|c|c|c|c|c|}
\hline \multirow{2}{*}{ No } & \multirow{2}{*}{ Obyek Biota } & \multicolumn{3}{|c|}{ Lokasi Penelitian } \\
\hline & & Stasiun I & Stasiun II & Stasiun III \\
\hline 1 & Ikan Gelodok & + & + & + \\
\hline \multirow[t]{5}{*}{2} & Crustacea & + & + & + \\
\hline & Crustacea (Kepiting Uca) & + & + & + \\
\hline & Crustacea (Kepiting Hitam) & + & + & + \\
\hline & Crustacea (Kepiting Beracun) & + & + & + \\
\hline & Crustacea (Kepiting Bakau) & + & + & + \\
\hline \multirow[t]{5}{*}{3} & Gastropoda & + & + & + \\
\hline & Gastropoda (Cerithidae cinglelata) & + & + & + \\
\hline & Gastropoda (Sari trunceria) & + & + & + \\
\hline & Gastropoda (polymesoda erosa) & + & + & + \\
\hline & Gastropoda (Toriacana licuncita) & + & + & + \\
\hline \multirow[t]{5}{*}{4} & Bivalvia & + & + & + \\
\hline & Bivalvia (Anodontia adentula) & + & + & + \\
\hline & Bivalvia (Tranchycardium rugasum) & + & + & + \\
\hline & Bivalvia (Tranchycardium angulatium) & + & + & + \\
\hline & Bivalvia (Austriella corrugata) & + & + & + \\
\hline
\end{tabular}

Berdasarkan hasil penelitian, (Lihat Tabel 5) setiap stasiun ditemukan obyek biota ikan gelodok, jenis crustacea, gastropoda, dan bivalvia.

\section{Analisis Kesesuaian Ekowisata Mangrove}

Berdasarkan hasil pengukuran yang telah diperoleh di lapangan yaitu ada 3 stasiun penelitian. Peneliti menganalisis kesesuian berdasarkan aspek penilaian yang disesuaikan dalam tabel parameter kesesuian ekowisata mangrove, perhitungan 
analisis kesesuaian kawasan berdasarkan (Yulianda, 2007). Hasil pengukuran dilapangan didapatkan nilai bobot dan skor di setiap stasiun (Lihat Tabel 5).

Tabel 5. Hasil Analisis Kesesuian Kawasan Ekowisata Mangrove.

\begin{tabular}{cccc}
\hline No & Lokasi Penelitian & IKW & Keterangan \\
\hline 1 & Stasiun I & $66 \%$ & S2 (Sesuai) \\
2 & Stasiun II & $66 \%$ & S2 (Sesuai) \\
3 & Stasiun III & $71 \%$ & S2 (Sesuai) \\
\hline
\end{tabular}

Nilai indeks kesesuian kawasan ekowisata mangrove pada (Tabel 7), menunjukan tingkat kelayakan ekowisata mangrove sebagai kesesuian kawasan ekowisata mangrove untuk dijadikan sebagai objek ekowisata. Hal ini memiliki nilai penting terhadap suatu pengelolaan suatu ekowisata. Berdasarkan hasil penelitian analisis kesesuian lokasi penelitian pada Stasiun I didapatkan nilai $66 \%$ kategori S2 (Sesuai), tidak jauh berbeda pada penelitian Johan (2016), menyatakan pada tutupan komunitas karang tertinggi kategori sesuai dengan nilai 50 - $83 \%$ yaitu pada semua titik lokasi pengamatan. Stasiun II didapatkan nilai $66 \%$ kategori S2 (Sesuai). Berbeda dengan hasil penelitian (Wibowo, 2015), menyatakan bahwa kesesuaian kawasan ekowisata mangrove di Kecamatan Kampung Melayu Kota Bengkulu memiliki nilai IKW (Indeks Kesesuian Wisata) sebesar 79 \% (Sangat Sesuai). Sedangkan Stasiun III didapatkan nilai $71 \%$ kategori S2 (Sesuai). Berbeda pada hasil penelitian (Sihotang dkk., 2014), menyatakan kesesuian kawasan ekowisata mangrove di Pantai Bali Desa Mesjid Lama Kecamatan Talawi Kabupaten Batu Bara Provinsi Sumatera Utara, dengan nilai IKW (Indeks Kesesuian Wisata) sebesar 94,87 (Sesuai).

Stasiun I didapatkan hasil analisis kesesuian ekowisata mangrove dari 5 parameter diantaranya : ketebalan mangrove $(\mathrm{m}) 153 \mathrm{~m}$ (Sesuai Bersyarat), kerapatan mangrove 12,50 (Ind/m2) kategori (Sesuai), jenis mangrove 8 jenis (Sangat Sesuai), pasang surut $(\mathrm{m})$ 0,68 $\mathrm{m}$ (Sangat Sesuai), dan obyek biota yang terdapat (lkan gelodok, crustacea yaitu kepiting uca, kepiting hitam, kepiting beracun, kepiting bakau, moluska yaitu Cerithidae cinglelata, Sari trunceria, polymesoda erosa, Toriacana licuncita, dan bivalvia yaitu Anodontia adentula, Tranchycardium angulatium, Austriella corrgata) dengan kategori (Sangat Sesuai).

Sedangkan pada Stasiun II didapatkan ketebalan mangrove $(\mathrm{m}) 185 \mathrm{~m}$ (Sesuai Bersyarat), kerapatan mangrove (m2) 11,41 (Ind/m2) kategori (Sesuai), jenis mangrove 9 jenis (Sangat Sesuai), pasang surut 0,68 m (Sangat Sesuai), dan obyek biota yang ditemukan diantaranya : (Ikan gelodok, crustacea yaitu kepiting uca, kepiting hitam, kepiting beracun, kepiting bakau, molusca yaitu Cerithidae cinglelata, San trunceria, polymesoda erosa, Toriacana licuncita, Bivalvia yaitu Anodontia adentula, Tranchycardium angulatium, Austriella corrgata) dengan kategori ( Sangat Sesuai). Selanjutnya pada Stasiun III didapatkan hasil analisis kesesuaian ekowisata mangrove dengan ketebalan mangrove $(\mathrm{m}) 204 \mathrm{~m}$ (Sesuai), kerapatan mangrove (m2) 10 (Ind/m2) kategori (Sesuai Bersyarat), jenis mangrove 10 jenis (Sangat Sesuai), pasang surut $(\mathrm{m})$ 0,68 $\mathrm{m}$ (Sangat Sesuai), dan obyek biota yang didapatkan pada stasiun ini diantaranya: (Ikan gelodok, crustacea yaitu kepiting uca, kepiting hitam, kepiting beracun, kepiting bakau, Gastropoda yaitu Cerithidae cinglelata, San trunceria, polymesoda erosa, Toriacana licuncita, Bivalvia yaitu Anodontia adentula, Tranchycardium angulatium, Austriella corrgata) dengan kategori (Sesuai).

Sehingga setelah dihitung dengan rumus IKW (Indeks Kesesuian Wisata) didapatkan hasil akhir pada Stasiun I mendapatkan nilai $66 \%$ masuk kategori S2 (Sesuai), Stasiun II mendapatkan nilai $66 \%$ masuk kategori S2 (Sesuai), Sedangkan pada Stasiun III mendapatkan nilai $71 \%$ masuk dalam kategori S2 (Sesuai) untuk dijadikan sebagai obyek ekowisata mangrove. Dari hasil ketiga lokasi stasiun penelitian yang didapatkan, maka Desa Kahyapu layak untuk dijadikan sebagai ekowisata mangrove karena 5 parameter yang dihitung memenuhi syarat selain itu memiliki keadaan mangrove yang masih alami dan pertumbuhanya sangat baik. 


\section{KESIMPULAN DAN SARAN \\ Kesimpulan}

Desa Kahyapu Pulau Enggano memiliki potensi untuk dijadikan sebagai objek ekowisata mangrove. Berdasarkan hasil penelitian pada Stasiun I didapatkan nilai IKW $66 \%$ (Sesuai), Stasiun II nilai IKW 66 \% (Sesuai) dan Stasiun III nilai IKW $71 \%$ (Sesuai).

\section{Saran}

Penulis menyarankan kedepanya perlu dilakukan penelitian lanjutan mengenai kesesuian dengan menggunakan SIG (Sistem Informasi Geografis) dan daya dukung kawasan ekowisata mangrove, agar dapat memberikan informasi yang lebih akurat mengenai ekowisata mangrove di Desa Kahyapu Pulau Enggano.

\section{DAFTAR PUSTAKA}

Agustini, N. T. 2014. Struktur Komunitas Ekosistem Mangrove di Desa Kahyapu Kecamatan Enggano Kabupaten Bengkulu Utara Provinsi Bengkulu. Program Studi Ilmu Kelautan. Fakultas Pertanian. Universitas Bengkulu.

Anam, R. 2012. Field Identifikation Guide To The Living Marine Resources Of Kenya. Departemen Rome. Italy.

Bengen, D.G. 2000. Pedoman Teknis Pengenalan dan Pengelolaan Ekosistem Mangrove, Pusat Kajian Sumberdaya Pesisir dan Lautan - Institut Pertanian Bogor : Indonesia.

Fahriansyah, dan D. Yoswaty. 2012. Pembangunan Ekowisata di Kecamatan Tanjung Balai Asahan, Sumatera Utara: Faktor Ekologis Hutan Mangrove. Ilmu dan Teknologi Kelautan Tropis. J. Vol. (4), No. 2: 346-359.

Johan, Y. 2016. Analisis kesesuaian dan daya dukung ekowisata bahari Pulau Sebesi, Provinsi Lampung. Prodi IImu Kelautan, Fakultas Pertanian, Universitas Bengkulu.

Noor,Y.R, M. Khazali, dan I N.N. Suryadiputra. 2006. Panduan pengenalan mangrove di indonesia. PHKA/WI-IP, Bogor.

Saru, A. 2014. Potensi Ekologis dan Pengelolaan Ekosistem Mangrove di Wilayah Pesisir. Cetakan Pertama. IPB Press.Kampus IPB Taman Kencana, Bogor Indonesia.

Sihotang, P.S. 2014. Kajian Kesesuaian Ekowisata Mangrove Di Pantai Bali Desa Mesjid Lama Kecamatan Talawi Kabupaten Batu Bara Provinsi Sumatera Utara. Skripsi. Program Studi Manajemen Sumberdaya Perairan, Fakultas Pertanian. Universitas Sumatera Utara. Sumatera Utara.

Sofian, A. Harahab, N dan Marsoedi. 2012. Kondisi Dan Manfaat Langsung Ekosistem Mangrove Desa Penunggul Kecamatan Nguling Kabupaten Pasuruan. ElHayah. Vol. 2, No. 2 Maret 2012 (56-63).

Ta'alidin, Z. Hartono, D. Nabiu, M. Sulistyo, B. dan Arianto, W. 2003. Laporan Penelitian dan Pemetaan Pulau Enggano Kabupaten Bengkulu Utara Tahun Anggaran 2003. Badan Perencanaan Pembangunan Daerah Kabupaten Bengkulu Utara.

Wibowo, 2015. Studi Kesesuaian Ekowisata Mangrove di Kecamatan Kampung Melayu Kota Bengkulu. Program Studi IImu Kelautan. Skripsi. Fakultas Pertanian. Universitas Bengkulu.

Yulianda,F. (2007). Ekowisata Bahari sebagai Alternatif Pemanfaatan Sumberdaya. 